\title{
AZ ANTIOXIDÁNS RENDSZER, MINT A BÜKK (FAGUS SYLVATICA L.) KLIMATIKUS ALKALMAZKODÓKÉPESSÉGÉNEK LEHETSÉGES INDIKÁTORA
}

\author{
Visiné Rajczi Eszter, Hofmann Tamás, Albert Levente és Mátyás Csaba
}

Soproni Egyetem, Erdőmérnöki Kar

\begin{abstract}
Kivonat
Különböző származású bükk (Fagus sylvatica L.) populációkon tanulmányoztuk a szimulált klímaváltozás hatásait. A klimatikus alkalmazkodást kémiai paraméterekkel jellemeztük, összehasonlítva a bucsutai származási kísérlet területén növekvő hat kiválasztott bükk származás (Farchau, Pidkamin, Torup, Gråsten, Bánokszentgyörgy, Magyaregregy) enzimes és nem-enzimes antioxidáns rendszereit. A kiválasztott egyedek leveleiben mértük az összfehérje-tartalmat, a peroxidáz (POD) és polifenol-oxidáz (PPO) enzim aktivitását, az ABTS (2,2'-azino-di-(3-etilbenzotiazolin)-6-szulfonsav) antioxidáns kapacitást, és meghatároztuk a polifenolok minőségi és mennyiségi spektrumait. A különböző bükk származások enzimes és nem-enzimes antioxidáns rendszereinek összehasonlító vizsgálata során megállapítottuk, hogy az áttelepitéssel szimulált klimatikus stresszre adott válaszok a genetikai alkalmazkodottságtól (az eredeti származási helytől) függően különböznek és a különbségek kémiai mérésekkel kimutathatók. A POD enzim aktivitás, az összfehérje-tartalom és egyes polifenolok az adaptáció kémiai indikátorai lehetnek, és hasznosithatók a klímaváltozás jövőbeli hatásainak elörejelzésében, és a bükk szaporítóanyag jövőbeli kiválasztásánál.
\end{abstract}

Kulcsszavak: levél antioxidáns rendszer, oxido-reduktáz enzimek, polifenol, Ellenberg-index, klímaváltozás, bükk származási kísérlet

\section{ANTIOXIDANT SYSTEM AS A POTENTIAL INDICATOR OF THE CLIMATIC ADAPTATION OF BEECH (FAGUS SYLVATICA L.)}

\begin{abstract}
The effect of simulated climate change was studied on populations of different beech (Fagus sylvatica L.) provenances. The climatic adaptation of six selected beech provenances (Farchau, Pidkamin, Torup, Gråsten, Bánokszentgyörgy, Magyaregregy), growing at the site of the beech provenance test of Bucsuta $(\mathrm{H})$ were compared by the assessment of their enzymatic and non-enzymatic antioxidant system. The total protein content, peroxidase (POD) and polyphenol oxidase (PPO) enzyme activities as well as ABTS (2,2'-azino-bis-(3-etylbenzothiazoline)-6-sulfonic acid) antioxidant capacity were measured from the leaves of selected trees. The identification and quantitative determination of major leaf polyphenols was also determined from the same samples. By the comparative analysis of the enzymatic and non-enzymatic antioxidant systems
\end{abstract}


of the provenances it was concluded that the selected chemical variables were suitable for the assessment of the climatic stress, simulated by the translocation of the investigated provenances. POD enzyme activity as well as total protein content and the concentrations of certian polyphenols could be potential chemical indicators of the adaptation process and could be used in the forecasting of the future effects of climate change and in the selection of propagation material in the future.

Keywords: leaf antioxidant system, oxidoreductase enzymes, polyphenols, Ellenberg index, climate change, beech provenance trials

\section{BEVEZETÉS}

A stressz a növényekben jelátviteli és génexpressziós változásokat vált ki, melyek nyomán módosul a fotoszintézis, a növekedés, a légzés, az anabolizmus, a katabolizmus stb. Válaszként a növények aktiválják a lokális és szisztemikus védelmi rendszerüket, melyekben elsősorban a gének, géncsoportok játszanak szerepet, de az eredményes válaszreakciók a növények környezet által befolyásolt fiziológiai állapotától is függenek.

A stresszfaktorok túlnyomó többsége oxidatív stresszt vált ki, amely nem más, mint a prooxidánsok és az antioxidánsok közt fellépő, a prooxidánsok javára történő egyensúly eltolódás (Sies 1991). Jelentős szerepet játszanak benne az élő szervezetek általános folyamataiban keletkező reaktív oxigénformák, melyek koncentrációja stresszhatásra megemelkedik. Főbb képviselőik a szuperoxid gyök $\left(\mathrm{O}_{2}{ }^{-}\right)$, a szinglet oxigén $\left({ }^{1} \mathrm{O}_{2}\right)$, a hidrogén-peroxid $\left(\mathrm{H}_{2} \mathrm{O}_{2}\right)$, valamint a hidroxil gyök (HO·) (Del Río 2015). A reaktív oxigénformák reakcióba léphetnek az élő anyag legtöbb komponensével, a folyamatok gyakran irreverzibilisek és láncreakció-szerüen tovább terjednek. Válaszként a növény aktiválja a reaktív oxigénformákat elimináló enzimes és nem-enzimes antioxidáns rendszereit. A glutation rendszer (Tausz et al 2004) és más specifikus stressz fehérjék, az oxidáz enzimek, illetve izoenzimjeik, és egyes polifenolok minőségi és mennyiségi spektrumaik változásain keresztül közvetve jellemzik a növényi stresszt, élettani markernek (biomarker) tekinthetök.

Kutatásaink az előrevetített klímaváltozással hazánkban erősen érintett bükk (Fagus sylvatica L.) alkalmazkodóképességének felderítésére irányultak. Célunk volt az áttelepítéssel szimulált klímaváltozással összefüggő stressztürő képesség (akklimáció, alkalmazkodás) jellemzése, és az alkalmazkodási teljesítmény minősítése. A bucsutai származási kísérlet területéről választott kísérleti alanyainkat egyszerre több stresszhatás is érheti, melyek befolyásolhatják a sejt és az egész szervezet müködését a génektől a növényi metabolitokig. Az ilyen körülményekhez való alkalmazkodás az általános védekezési rendszer állapotának meghatározásával jellemezhető, követésére az oxidatív stressz kutatása nyújt lehetőséget.

2015 és 2017 között vizsgáltuk a bucsutai származási kísérletben kiválasztott hat bükk származás (Farchau, Pidkamin, Torup, Gråsten, Bánokszentgyörgy, Magyaregregy) (1. ábra) antioxidáns rendszerének általános állapotát és annak enzimes komponenseit. A kiválasztott egyedek leveleit felhasználva összehasonlítottuk az összfehérje-tartalmakat, valamint a peroxidáz (POD) és polifenol-oxidáz (PPO) enzimek aktivitását. A POD és PPO antioxidáns enzimek bizonyítottan részt vesznek a növények stressz folyamatokkal szembeni védekezési mechanizmusaiban (Albert et al 2002), így bükk esetében is indikátorai lehetnek a klímához való alkalmazkodásnak (Puccinelli et al 1998, Zolfaghari et al 2010).

Az enzimes antioxidáns rendszerek vizsgálata során nyert korábbi mérési eredményeinket - a teljes antioxidáns rendszer müködésének megismerése érdekében - összehasonlítottuk a nem-enzimes antioxidáns rendszerek vizsgálata során előzetesen nyert eredményeinkkel. A nem-enzimes antioxidáns rendszer tekintetében vizsgálatainkat a polifenol-típusú vegyületekre végeztük el. Mindkét mérési sorozatnál azonos egyedekről vettük a levél mintákat. A nem-enzimes antioxidáns rendszer vizsgálatánál elsősorban a polifenol alapú adaptációs válaszokat kutattuk, mivel a polifenolok jelentős szerepe a stressz elleni védekezésben bizonyított (Dübeler et al 1997). Mértük a kísérleti alanyok ABTS (2,2'-azino-di-(3-etilbenzotiazolin)-6-szulfonsav) antioxidáns kapacitását is, mely átfogó képet ad az oxidatív stresszről (Hassan et al 2017). A vizsgált bükk levelekböl 
44 polifenolt azonosítottunk (38-at név szerint) és kiválasztottuk közülük a leghatékonyabb polifenolos antioxidánsokat, melyek szignifikánsan járulhatnak hozzá a bükk antioxidáns tulajdonságaihoz, és ezen keresztül jelentős szerepet játszhatnak a védekezési és adaptációs folyamatokban (Hofmann et al 2017).

Mind az enzimes, mind a nem-enzimes antioxidáns rendszerek vizsgálata során nyert mérési eredményeket korreláltattuk az állományok klimatikus paramétereivel (Ellenberg-index - EQ; ökológiai távolság $-\triangle E Q$ ), és az állományok „teljesítményével” (átlagos mellmagassági törzsátmérő a mintavétel idején). Az ökológiai távolság (ecodistance, Mátyás 1994) a kísérleti helyszín és a származási helyek Ellenbergindexének különbsége $(\Delta \mathrm{EQ})$ (1. táblázat), az áttelepítéssel szimulált klímaváltozás jellemzője. Az index használhatóságát a bükk adaptációjának kutatásában korábbi munkák is alátámasztják (Fang \& Lechowicz 2006, Czúcz et al 2013).

Kutatásainkkal bizonyítani kívántuk, hogy a különbözö bükk származások stresszválaszai metabolitjaik kémiai vizsgálatával jellemezhetők és a metabolitok között létezhetnek sztressz-indikátorok, melyek molekuláris szinten karakterizálják az akklimációt, ill. adaptációt. A kutatás egy, eddig nemzetközi szinten sem tanulmányozott kérdés feltáró vizsgálata volt, általános trendek, összefüggések azonositása céljából. Ennek megfelelően a kiválasztott populációk száma és összetétele, a mintázás mennyisége, az évenkénti ismétlések száma korlátozott volt.

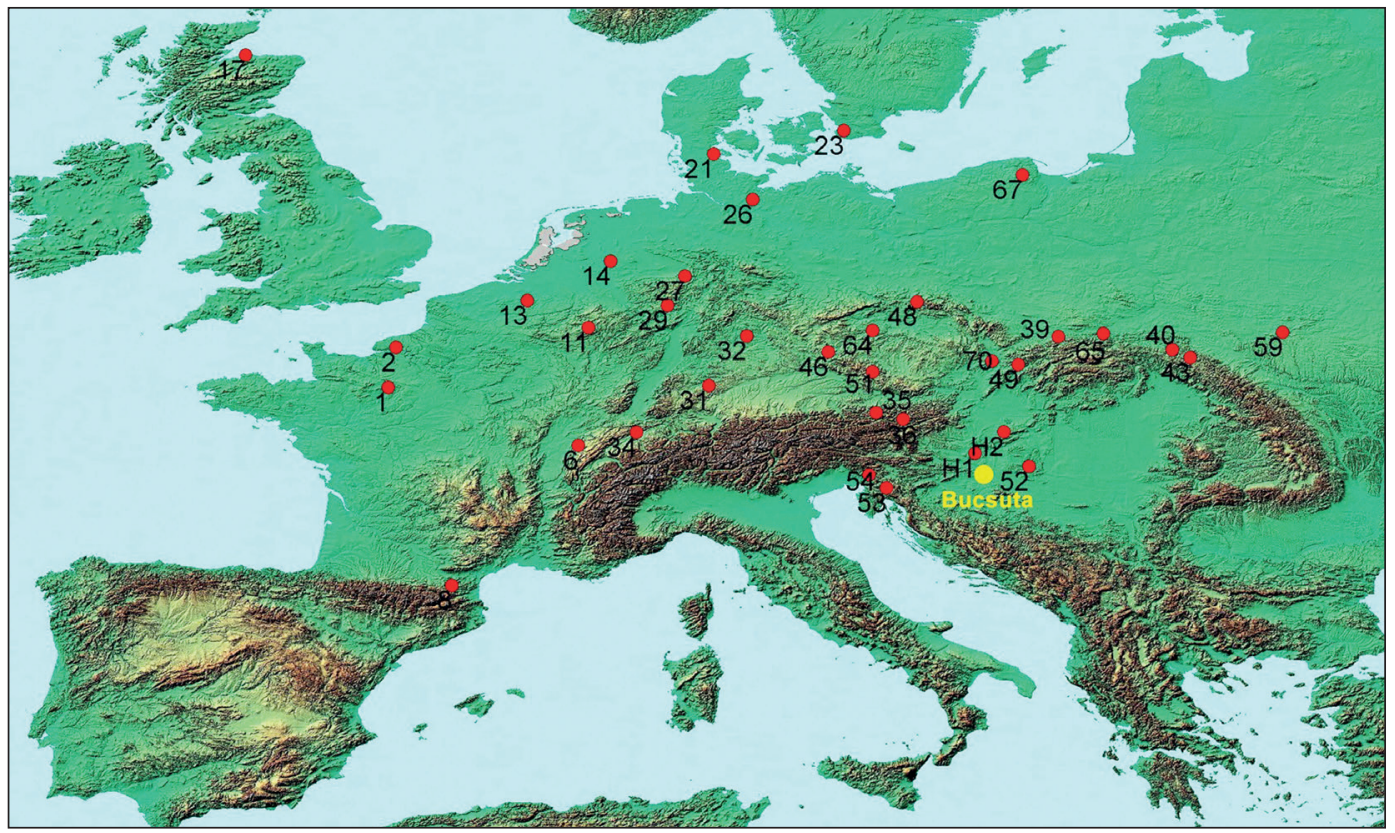

1. ábra: A Bucsuta-i kísérlet populációi és a kiválasztott származási helyek 21: Gråsten (DK), 23: Torup (S), 52: Magyaregregy (H), H1: Bánokszentgyörgy (H), 59: Pidkamin (UA), 26: Farchau (D)

Figure 1: The beech provenance test in Bucsuta and the investigated populations: 21: Gråsten (DK), 23: Torup (S), 52: Magyaregregy (H), H1: Bánokszentgyörgy (H), 59: Pidkamin (UA), 26: Farchau (D)

A Zalaerdö Zrt. Bánokszentgyörgyi Erdészete területén 1998-ban a Bucsuta 10/b erdörészletbe 15 országból 36 bükk származást (1. ábra) telepítettek 3 ismétlésben (Horváth \& Mátyás 2014, 2016). Az eltérō klimákat képviselő hat származás levél mintái erről a kísérleti területről származtak. A származások kiválasztásának szempontja az volt, hogy eltérő klímából származó populációkat hasonlítsunk össze, melyek közül egyesek inkább mérsékelt kontinentális (magyarországi származások), egyesek szélsőséges kontinentális (Pidkamin), míg mások atlanti klíma hatása alatt álltak. 
1. táblázat: A Bucsután szereplő származások földrajzi adatai, és múltbeli (1950-2000) éves csapadék és júliusi középhömérséklet átlagaik, valamint az Ellenberg- index-szel kifejezett ökológiai távolságuk $(\triangle E Q)$ a bucsutai 15 éves átlagadatoktól

(Horváth \& Mátyás 2014)

Table 1: Geographic data, annual precipitation and July mean temperature of provenances in the period 1950-2000, as well as their ecological transfer distance from the 15-year means of Bucsuta, expressed in Ellenberg's climate quotients ( $\triangle E Q$ )

(Horváth \& Mátyás 2014)

\begin{tabular}{|l|c|c|c|c|c|c|}
\hline \multicolumn{1}{|c|}{ Származás neve } & Ország & Tszfm $(\mathbf{m})$ & $\begin{array}{c}\text { Júliusi közép- } \\
\text { hömérséklet }\left({ }^{\circ} \mathrm{C}\right)\end{array}$ & $\begin{array}{c}\text { Éves csapadék } \\
(\mathbf{m m})\end{array}$ & EQ & $\Delta$ EQ \\
\hline Farchau & D & 55 & 17,3 & 676 & 25,6 & 3,86 \\
\hline Pidkamin & UA & - & 18,1 & 612 & 29,6 & $-0,13$ \\
\hline Torup & S & 40 & 16,6 & 634 & 26,2 & 3,27 \\
\hline Gråsten & DK & 45 & 15,8 & 780 & 20,3 & 9,19 \\
\hline Magyaregregy & H & 400 & 19,0 & 707 & 26,9 & 2,57 \\
\hline Bánokszentgyörgy & H & 200 & 20,0 & 747 & 26,8 & 2,67 \\
\hline
\end{tabular}

\section{ANYAG ÉS MÓDSZER}

A mintavételek időpontjai: a nem enzimes antioxidáns rendszer vizsgálatához 2013. június, az enzimes antioxidáns rendszer vizsgálatához 2015-2017 június vége, július eleje. Minden populációból 4 törzset választottunk, a megjelölt fákról 20 árnyéklevelet és 20 fénylevelet vettünk 3-6 méter magasságból: a 40 levél képezte az adott egyedet reprezentáló levélmintát. A mintákat feldolgozásig szárazjégben tároltuk, extrakció előtt ledaráltuk. A levélminták kémiai paramétereit meghatároztuk, majd az adott származáshoz tartozó 4 törzs levélmintáinak eredményeit átlagoltuk, és így kaptuk az adott évjáratot és származást reprezentáló átlagértéket és szórást.

\section{Enzim vizsgálatok}

Extrakció: 0,5 g homogenizált levélhez $10 \mathrm{ml}$ foszfát puffert adtunk ( $\mathrm{pH}=5,6 ; 80 \mathrm{~g} / \mathrm{l}$ PVP40), majd 3-4 percig ráztuk, ezután 10 percig 6000/min fordulatszámon centrifugáltuk.

Összfehérje-tartalom meghatározása: Bradford-módszerrel történt (Bradford 1976). Standardnek 92\%-os BSA-t (szérum albumin) használtunk.

$P O D$ aktivitás meghatározása: Abszorbancia mérés $480 \mathrm{~nm}$-en (Shannon et al 1966). 0,01 $\Delta \mathrm{A} /$ perc-et vettünk 1 Unit-nak. Mintánként három párhuzamos mérést végeztünk.

PPO aktivitás meghatározása: Abszorbancia mérése $420 \mathrm{~nm}$-en (Flurkey et al 1978). 0,001 $\Delta \mathrm{A} /$ perc-et vettük 1 Unit-nak. Mintánként három párhuzamos mérést végeztünk.

\section{Nem-enzimes antioxidánsok vizsgálata}

Extrakció: a ledarált levélmintákat $(0,15 \mathrm{~g}) 15 \mathrm{ml}$ 4:1 metanol: víz eleggyel extraháltuk 24 órán keresztül sötétben mágneses keverővel. Az extraktumokat cellulóz-acetát $(0,45 \mu \mathrm{m})$ fecskendős szűrőn szűrtük és a kromatográfiás vizsgálatok előtt kétszeresére higítottuk.

Folyadékkromatográfiás vizsgálatok: a polifenolos antioxidánsok elválasztásához, azonosításáhozés menynyiségi meghatározásához nagy-hatékonyságú folyadékkromatográfiás elválasztást, valamint fotodiódasorosés tandem tömegspektrometriás detektálást (HPLC-PDA-ESI-MS/MS) alkalmaztunk (Hofmann et al 2017). 
ABTS antioxidáns kapacitás: A meghatározást Stratil et al (2007) módszere alapján végeztük el trolox sztenderdet alkalmazva.

\section{Statisztikai kiértékelés}

A korrelációs vizsgálatokat és a variancia analízist adott szignifikancia szintek mellett a Statistica 12 software (StatSoft Inc., Tulsa, USA) segítségével végeztük.

\section{Klíma-index meghatározás}

Ellenberg-index (EQ): a legmelegebb hónap (július, $T_{07}\left[{ }^{\circ} \mathrm{C}\right]$ ) középhőmérsékletének és az éves csapadék $\left(P_{\text {ann }},[\mathrm{mm}]\right)$ hányadosának 1000-szerese (Ellenberg 1988):

$$
E Q=1000 \cdot T_{07} \cdot P_{\text {ann }}{ }^{-1}
$$

Mivel Bucsután meteorológiai mérőállomás létesítése nem volt megoldható, ezért a tőle 18 km-re fekvő nagykanizsai állomás 1998-2013-as megfigyelési időszakra vonatkozó adatait használtuk fel az elemzéshez (Horváth \& Mátyás 2014). A származások helyszínére vonatkozó hőmérséklet- és csapadékadatok a WorldClim (www.worldclim.org) adatbázisból származnak, amely egy 50 éves intervallum (1950-2000) interpolált adatait tartalmazza.

Ökológiai távolság ( $\triangle \mathrm{EQ}$ ): a kísérleti helyszín és a származási helyek Ellenberg-indexének különbsége (Mátyás 1994). Az áttelepítéssel létrejött klímaváltozás mértékét adja meg. Pozitiv értéke melegedést/ szárazodást, a negatív hűvösebb, nedvesebb klímába kerülést jelent (1. táblázat).

\section{EREDMÉNYEK ÉS MEGVITATÁSUK}

\section{Enzimes antioxidáns rendszer}

Mértük a kiválasztott származások levelében az összfehérje tartalmat, valamint a POD és PPO enzimek aktivitását. A primer mérési adatokat egy korábbi cikkünk tartalmazza (Visiné et al 2017). Az eredményeket összevetettük az állományok klimatikus paramétereivel (ökológiai távolság, $\Delta \mathrm{EQ}$ ), és az állományok „teljesítményével" (átlagos mellmagassági törzsátmérő). Arra kerestünk választ, hogy az összfehérje tartalom és a POD és PPO enzimek aktivitása összefüggésbe hozható-e a származások ökológiai távolságával (azaz a klimatikus stressz mértékével) és teljesítményével, lehetnek-e a különböző származások adaptációjának indikátorai.

Az összfehérje-tartalom, a POD és PPO enzimek, az ökológiai távolság változás és az átlagos mellmagassági átmérő korrelációs elemzésének eredményeit a 2. táblázat tartalmazza. 
2. táblázat: Korrelációs mátrixok a 2015-2016-2017-es év adataival, szignifikáns korrelációk $(p<0,15)$ piros színnel jelölve Table 2: Correlation matrices using the data from the years 2015, 2016, 2017

\begin{tabular}{|c|c|c|c|c|c|}
\hline 2015 & $\begin{array}{l}\text { Összfehérje- } \\
\text { tartalom }(\mu \mathrm{g} / \mathrm{g})\end{array}$ & $\begin{array}{l}\text { POD } \\
(U / \mu g)\end{array}$ & 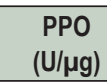 & $\Delta \mathrm{EQ}$ & $\begin{array}{l}\text { Átl. mellmagassági } \\
\text { átmérö }(\mathrm{cm})\end{array}$ \\
\hline Összfehérje-tartalom ( $\mu \mathrm{g} / \mathrm{g}$ ) & 1,0000 & $-0,6742$ & $-0,7552$ & 0,8542 & $-0,2511$ \\
\hline $\mathrm{POD}(\mathrm{U} / \mu \mathrm{g})$ & & 1,0000 & 0,1614 & $-0,8083$ & 0,5754 \\
\hline $\mathrm{PPO}(\mathrm{U} / \mu \mathrm{g})$ & & & 1,0000 & $-0,4391$ & $-0,3931$ \\
\hline$\triangle \mathrm{EQ}$ & & & & 1,0000 & $-0,3407$ \\
\hline Átl. mellmagassági átmérő (cm) & & & & & 1,0000 \\
\hline 2016 & $\begin{array}{l}\text { Összfehérje- } \\
\text { tartalom }(\mu \mathrm{g} / \mathrm{g})\end{array}$ & $\begin{array}{l}\text { POD } \\
(\mathrm{U} / \mu \mathrm{gg})\end{array}$ & $\begin{array}{l}\text { PPO } \\
(\mathrm{U} / \mu \mathrm{g})\end{array}$ & $\Delta \mathrm{EQ}$ & $\begin{array}{l}\text { Átl. mellmagassági } \\
\text { átmérö }(\mathrm{cm})\end{array}$ \\
\hline Összfehérje-tartalom ( $\mu \mathrm{g} / \mathrm{g}$ ) & 1,0000 & $-0,2856$ & $-0,0751$ & 0,7077 & $-0,0321$ \\
\hline $\mathrm{POD}(\mathrm{U} / \mu \mathrm{g})$ & & 1,0000 & 0,4301 & $-0,4739$ & 0,8327 \\
\hline $\mathrm{PPO}(\mathrm{U} / \mu \mathrm{g})$ & & & 1,0000 & $-0,7370$ & 0,5826 \\
\hline$\triangle \mathrm{EQ}$ & & & & 1,0000 & $-0,3390$ \\
\hline Átl. mellmagassági átmérő (cm) & & & & & 1,0000 \\
\hline 2017 & $\begin{array}{c}\text { Összfehérje- } \\
\text { tartalom }(\mu \mathrm{g} / \mathrm{g})\end{array}$ & $\begin{array}{l}\text { POD } \\
(\mathrm{U} / \mu \mathrm{g})\end{array}$ & 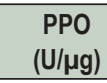 & $\Delta \mathrm{EQ}$ & $\begin{array}{l}\text { Átl. mellmagassági } \\
\text { átmérő }(\mathrm{cm})\end{array}$ \\
\hline Összfehérje-tartalom ( $\mu \mathrm{g} / \mathrm{g})$ & 1,0000 & $-0,0243$ & $-0,0155$ & 0,6792 & 0,1906 \\
\hline $\mathrm{POD}(\mathrm{U} / \mu \mathrm{g})$ & & 1,0000 & $-0,3096$ & $-0,4445$ & 0,9414 \\
\hline $\mathrm{PPO}(\mathrm{U} / \mu \mathrm{g})$ & & & 1,0000 & $-0,3056$ & $-0,0675$ \\
\hline$\Delta \mathrm{EQ}$ & & & & 1,0000 & $-0,3536$ \\
\hline Átl. mellmagassági átmérő (cm) & & & & & 1,0000 \\
\hline
\end{tabular}

Összfehérje-tartalom vs. ökológiai távolság ( $\triangle E Q)$. Megállapítottuk, hogy mind a három évben szignifikáns pozitív kapcsolat van az összfehérje-tartalom és az ökológiai távolság között. A pozitív kapcsolatot a 2017. évre vonatkozó 2. ábra szemlélteti.

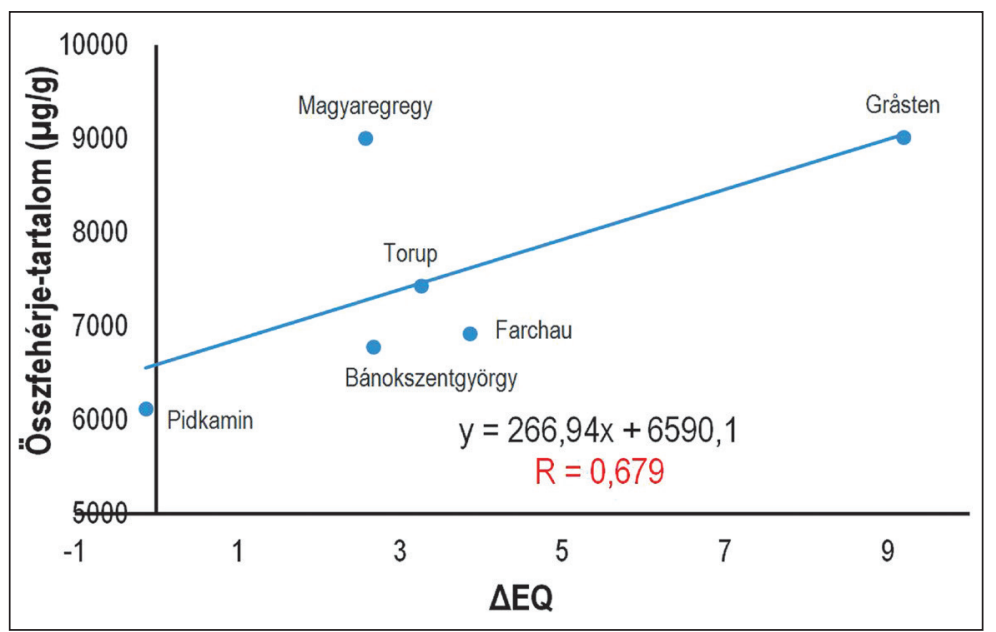

2. ábra: Korreláció az Ellenberg-index változása $(\triangle E Q)$ és az összfehérje-tartalom között, a 2017-ben vett levél minták esetében Figure 2: Correlation between change of Ellenberg's drought index ( $\triangle E Q$ ) and total protein content using the data from year 2017 
Az eredmények alapján azok a származások, amelyek eredetileg melegebb és szárazabb klímához adaptálódtak (pl. Pidkamin), alacsonyabb összfehérje tartalommal jellemezhetők és általában jobb növekedési paramétereket is mutatnak, mint a nagyobb ökológia távolsággal $(\Delta \mathrm{EQ})$ jellemzett származások (pl. Gråsten), melyek adaptációs képessége gyengébb. A helyi körülményekhez való kismértékű alkalmazkodást nemcsak a gyenge növekedés (3. ábra), hanem a szemmel látható magas mortalitás is bizonyítja.

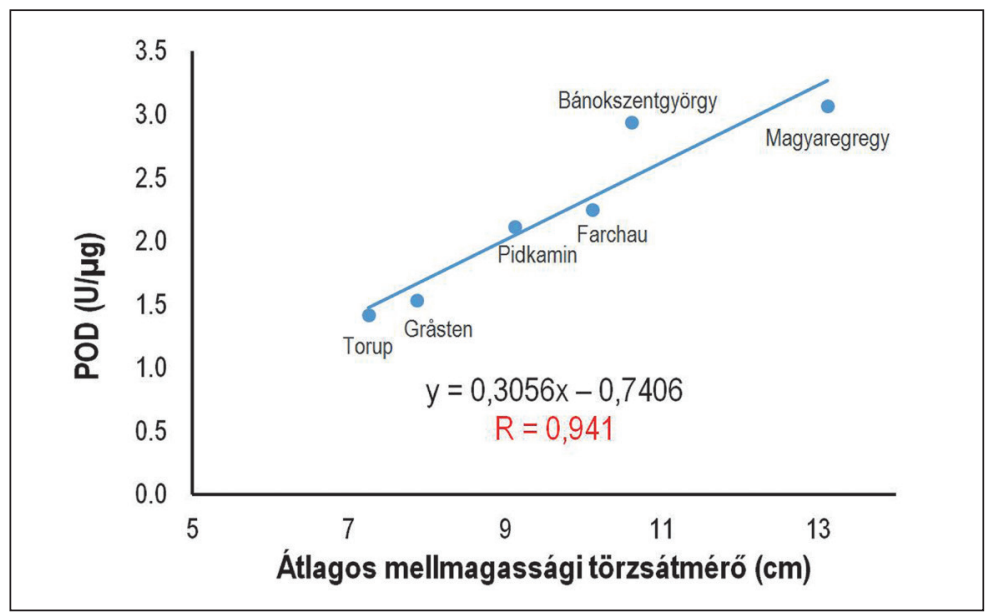

3. ábra: Korreláció az átlagos mellmagassági törzsátméró és a POD aktivitás között (2017-ben vett levél minták)

Figure 3: Correlation between average stem diameter and POD enzyme activity using the data from year 2017

$P O D$ enzim aktivitás vs. átlagos mellmagassági törzsátmérő. Szignifikáns pozitív kapcsolatot $(p<0,15)$ mutattunk ki a származások átlagos mellmagassági törzsátmérője és a POD enzim aktivitása között a 2016-17 években (3. ábra).

Az ábra jól mutatja, hogy a legrosszabb teljesítményü, azaz a legkisebb átlagos mellmagassági törzsátmérővel rendelkező, gyenge megmaradású populációk (Gråsten, Torup) esetében a legalacsonyabb a POD enzim aktivitása. Érdekes módon, a Pidkamin származás inkább a gyenge megmaradású populációkhoz van közelebb a POD akitivitás és az átmérő tekintetében, azonban ennél a származásnál a viszonylag kicsi átmérőhöz rendkívül nagy átlagos törzsmagasság társul, amely a 3. ábra kiértékelésében nem mutatkozik meg. Egy jövőbeli, átlagos törzsmagasságot figyelembe vevő kiértékelés ezeket a hatásokat is tükrözheti, mivel azonban csak az átlagos mellmagassági törzsátmérő terepi felmérése történt csak meg, ilyen kiértékelést a jelen cikk nem tartalmaz.

A megállapított korrelációs összefüggések hasonló tendenciát mutattak mindhárom évben, noha a 2015-ös év adataira a korrelációs összefüggés az alkalmazott sziginifikancia szint mellett nem szignifikáns. A rendkívül jó összefüggés a POD enzim aktivitás és az átlagos mellmagassági törzsátmérő között felveti a POD enzim aktivitás indikátor szerepének lehetőségét, például korai tesztben, az alkalmazásra előirányzott származások ellenőrzésénél.

\section{Nem-enzimes antioxidáns rendszer szerepe}

Kivontuk, elválasztottuk és azonosítottuk a bükk levelek polifenoljait. Összesen 44 vegyületet azonosítottuk, ebből 38-at név szerint. A mérési körülményeket és az összes mérési eredményt egy korábbi szakcikkünk tartalmazza (Hofmann et al 2017). 
A 4. ábra egy bükk származás levél extraktumának PDA kromatogramját szemlélteti, és tartalmazza az azonositott vegyületek listáját is.

Az azonosított vegyületek mennyiségét egy általunk kidolgozott kromatográfiás módszerrel mértük. Meghatároztuk a levélkivonatok antioxidáns kapacitását is az ABTS módszer alapján. Minden származás esetén minden azonosított polifenol vegyületre megadtuk a koncentrációk és az ABTS antioxidáns kapacitás átlagértékét, és ezt egybevetettük az átlagos mellmagassági törzsátmérővel, valamint az EQ értékkel.

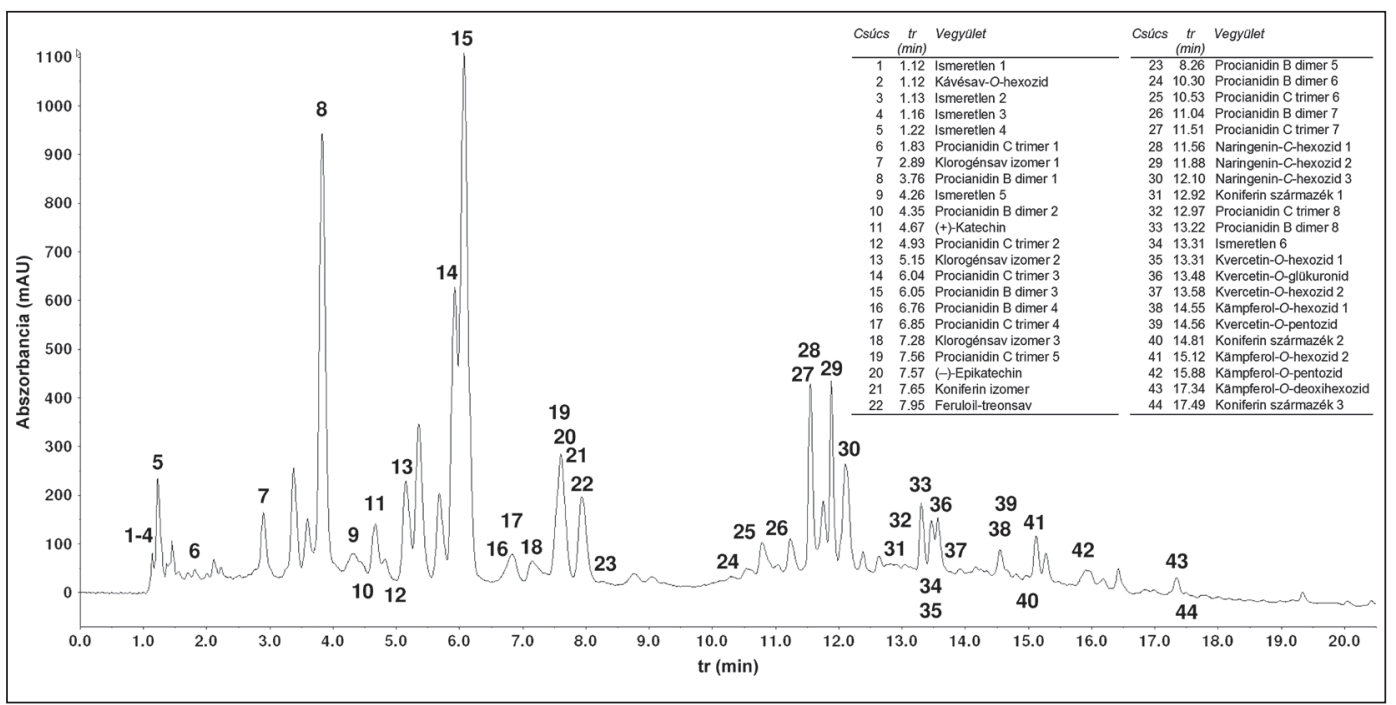

4. ábra: A bükk levél kivonat PDA (250-380 nm) kromatogramja

Figure 4: The typical PDA (250-380 nm) chromatogram of a beech leaf extract

Megállapítottuk, hogy a legrosszabb teljesítménnyel rendelkező állományok (Gråsten, Torup) esetében a legmagasabb az ABTS antioxidáns kapacitás. Feltételezhető, hogy ezekben a származásokban az áttelepités nagyobb stresszt váltott ki, a magasabb antioxidáns kapacitás erre adott válasznak tekinthető. Ezekben a származásokban egyes polifenol vegyületek mennyisége is kiemelkedően magas (Kávésav-O-hexozid, Ismeretlen 2; Kvercetin-O-hexozid 1 és 2; Kvercetin-O-pentozid; Kämpferol-0-pentozid), vagy meglepően alacsony (Ismeretlen 1, 3 és 6; Procianidin B dimer 5 és 6; Procianidin C trimer 6).

Elvégeztük a stresszválaszt általánosan jelző ABTS antioxidáns kapacitás, a polifenolok, az Ellenberg index és az átlagos mellmagassági törzsátmérő mérésénél nyert primer adatok korrelációs vizsgálatát az egyes származásokra. A korrelációs vizsgálatoknál a mérési eredmények átlagértékeit használtuk fel. Az n=6 elemszám és a $p<0,05$ feltétel mellett a kritikus $R$ érték 0,812 volt, tehát $|R| \geq 0,812$ esetében szignifikáns a kapott korreláció.

ABTS antioxidáns kapacitás vs. polifenol koncentráció. Feltételeztük, hogy az ABTS antioxidáns kapacitás és az egyes polifenolok koncentrációi között fennálló szignifikáns pozitív korreláció azt jelzi, hogy az adott vegyület "erős" antioxidáns, szignifikánsan járul hozzá a levelek antioxidáns tulajdonságaihoz és jelentős szerepe lehet a védekezelési, adaptációs folyamatokban. A korrelációs vizsgálat alapján a vizsgált bükk levelekben a leghatékonyabb (legmagasabb $R$ értékkel rendelkezö) antioxidánsok a $p<0,05$ feltétel figyelmebevételével a Kvercetin-O-hexozid $1(\mathrm{R}=0,937)$, Kvercetin-O-hexozid $2(\mathrm{R}=0,889)$, Koniferin származék $2(R=0,919),(+)-K a t e c h i n(R=0,873)$, ()-Epikatechin $(R=0,903)$, Kvercetin-O-pentozid $(R=0,876)$, KávésavO-hexozid $(R=0,872)$, Kämpferol-O-hexozid $2(R=0,815)$, Procianidin B dimer $3(R=0,825)$, Procianidin C trimer 
$3(R=0,870)$ és Procianidin $C$ trimer $4(R=0,817)$. Egyes vegyületek esetében szignifikáns negatív korrelációt találtunk $(R<-0,812)$, ezeknek a vegyületeknek feltételezhetően szignifikáns ABTS prooxidáns hatása van a bükk levél kivonatokban. Megállapítottuk, hogy az izomerek antioxidáns hatékonysága is jelentősen eltérő lehet (különösen a Procianidin B és C izomerek esetében).

$E Q$ értékek vs. polifenol koncentráció. A polifenolok koncentrációi és az $E Q$ értékek közötti korrelációk alapján megállapítottuk, hogy a magasabb EQ-val rendelkező (melegebb és szárazabb régiókból származó) bükk származások alacsony koncentrációban tartalmaznak több, nagy antioxidáns hatékonysággal jellemezhető vegyületet (pl. (+)-Katechin, Procianidin C trimer 3 és Procianidin B dimer 4). Ezt a megállapitást a vegyületek koncentrációi és az EQ értékek közötti szignifikáns negatív korrelációk bizonyítják (Hofmann et al 2017). A mérések alapján kijelenthető, hogy azok a származások, melyek eredetileg melegebb és szárazabb klímához adaptálódtak evolúciójuk során, nem termelnek megemelkedett mennyiségben hatékony és erős antioxidánsokat, mivel a bucsutai kísérleti körülmények között nincsenek fokozott stressznek kitéve, ill. jól alkalmazkodtak a klimatikus körülményekhez. Ezek a származások általában jobb növekedési paraméterekkel is rendelkeztek, mint az alacsonyabb EQ-jú származások, melyek adaptációs képessége gyengébb. Ezt a megállapitást korábbi adatok is megerősítik (Horváth \& Mátyás 2016).

Mellmagassági törzsátmérő vs. polifenol koncentráció. Az egyes vegyületek koncentrációi és a mellmagassági törzsátmérő közötti korrelációk alapján megállapítható, hogy egyes vegyületek koncentrációi közvetlen, szignifikáns pozitív kapcsolatban állnak az átlagos mellmagassági átmérővel: Ismeretlen $1(R=0,934)$, Ismeretlen $3(R=0,867)$, Ismeretlen $4(R=0,821)$. Ezek a vegyületek markerei lehetnek a bükk származások klimatikus adaptációjának és teljesítményének.

\section{ÖSSZEFOGLALÁS}

Különböző bükk származások enzimes és nem-enzimes antioxidáns rendszereinek összehasonlító vizsgálata során megállapítottuk, hogy az áttelepítéssel szimulált klimatikus stresszre adott válaszok a genetikai alkalmazkodottságtól (az eredeti származási helytöl) függően különböznek, és a különbségek kémiai mérésekkel kimutathatók. Az enzimes és nem-enzimes antioxidáns rendszerek vizsgálata során levont következtetéseink összhangban vannak.

Az eredmények alapján azok a származások (pl. Pidkamin), melyek eredetileg melegebb és szárazabb klímához adaptálódtak, anyagcseréjük során nem termelnek megemelkedett mennyiségben hatékony és erős polifenolos antioxidánsokat, mivel a bucsutai kísérleti körülmények között nincsenek fokozott stressznek kitéve, ill. jól alkalmazkodtak a klimatikus körülményekhez, és jobb növekedési paraméterekkel is rendelkeznek.

A legrosszabb teljesitménnyel rendelkező állományok (Gråsten, Torup) ABTS antioxidáns kapacitása és egyes polifenol vegyületeik koncentrációja kiemelkedően magas, míg a POD enzim aktivitások itt mutatják a legalacsonyabb értékeket. Feltételezhetö, hogy ezekben a származásokban az áttelepités nagyobb stresszt váltott ki, a megemelkedett antioxidáns kapacitás és polifenol koncentráció és a lecsökkent POD enzim aktivitás erre adott válasznak tekinthető.

Az összfehérje-tartalom, a POD aktivitás, az ABTS antioxidáns kapacitás, valamint egyes polifenol vegyületek koncentrációi a klimatikus adaptáció olyan indikátorai lehetnek, melyek képesek előre jelezni az áttelepítésből adódó stressz mértékét és az adaptációs készséget.

Jövőbeli célunk vizsgálatainkat kiterjeszteni és bővíteni más állományok bevonásával illetve más enzimes (pl. szuperoxid diszmutáz, glutation reduktáz) és nem-enzimes (glutation, aszkrobinsav) antioxidánsok meghatározásával, valamint a kísérleti adatok többváltozós statisztikai kiértékelése az átlagos törzsmagasság bevonásával. 
Következtetéseink egy része összhangban van a korábbi erdészeti, ökológiai témájú kutatások megállapításaival és hasznosítható a klímaváltozás jövőbeli hatásainak előre jelzésénél és a bükk szaporítóanyagok jövőbeli kiválasztásánál.

\section{KÖSZÖNETNYILVÁNÍTÁS}

Köszönjük a Zalaerdő Zrt. Bánokszentgyörgyi Erdészetének a kísérleti helyszín biztosítását. A kutatás a VKSZ_12-1-2013-0034 Agrárklíma 2 projekt támogatásával valósult meg.

\section{FELHASZNÁLT IRODALOM}

Albert L., Hofmann T., Visi-Rajczi E., Rétfalvi T., Németh Zs. I., Koloszár J. et al. 2002: Relationships Among Total Phenol and Soluble Carbohydrate Contents And Activities of Peroxidase and Polyphenol Oxidase in Red-Heartwooded Beech (Fagus sylvatica L.). 7th European Workshop on Lignocellulosics and Pulp, Turku/Abo, Finnland, Proceedings 253256.

Bradford M. M. 1976: A rapid sensitive method for the quantisation of microgram quantities of protein utilising the principle of protein-dye binding. Analytical Biochemistry 72: 248-254. DOI: 10.1006/abio.1976.9999

Czúcz B., Gálhidy L. \& Mátyás Cs. 2013: A bükk és a kocsánytalan tölgy elterjedésének szárazsági határa. Erdészettudományi Közlemények 3: 39-53.

Del Río L. A. 2015: ROS and RNS in plant physiology: an overview. Journal of Experimental Botany 66 (10): 2827-37. DOl: 10.1093/jxb/erv099. Epub 2015 Apr 7

Dübeler A., Voltmer G., Gora V., Lunderstädt J. \& Zeeck A. 1997: Phenols from Fagus sylvatica and their role in defence against Cryptococcus fagisuga. Phytochemistry 45: 51-57. DOI: 10.1016/s0031-9422(96)00771-6

Ellenberg H. 1988: Vegetation ecology of Central Europe, 4th ed. Cambridge University Press.

Fang J. \& Lechovicz M. J. 2006: Climatic limits for the present distribution of beech (Fagus sylvatica L.) species in the world. Journal of Biogeography 33: 1804-1819. DOI: 10.1111/j.1365-2699.2006.01533.x

Flurkey W. H. \& Jen J. J. 1978: Peroxidase and polyphenol oxidase activities in developing peaches. Journal of Food Science 43: 1826-1829. DOI: 10.1111/j.1365-2621.1978.tb07424.x

Hassan W., Noreen H., Rehman S., Gul S., Kamal M. A., Kamdem J. P. et al. 2017: Oxidative Stress and Antioxidant Potential of One Hundred Medicinal Plants. Current Topics in Medical Chemistry 17(12): 1336-1370. DOI: 10.2174/1 568026617666170102125648

Hofmann T., Tálos-Nebehaj E. \& Albert L. 2017: Leaf polyphenols as indicators of climatic adaptation of Beech (Fagus sylvatica L.) - an HPLC-MS/MS via MRM approach. International Labmate 42 (3): 12-14.

Horváth A. \& Mátyás Cs. 2014: Növedékcsökkenés elörevetítése egy bükk származási kísérlet alapján. Erdészettudományi Közlemények 4: 91-99.

Horváth A. \& Mátyás Cs. 2016: The Decline of Vitality Caused by Increasing Drought in a Beech Provenance Trial Predicted by Juvenile Growth. South-east European Forestry 7 (1): 21-28. DOI: 10.15177/seefor.16-06

Mátyás Cs. 1994: Modelling climate change effects with provenance test data. Tree Physiology 14: 797-804. DOI: 10.1093/ treephys/14.7-8-9.797

Puccinelli P., Anselmi N. \& Bragaloni M. 1998: Peroxidases: suitable markers of air pollution in trees from urban environments. Chemosphere 36 (4-5): 889-894. DOl: 10.1016/s0045-6535(97)10143-6

Shannon L. M., Kay E. \& Lew J. Y. 1966: Peroxidase isoenzymes from horseradish roots. The Journal of Biological Chemistry 241: 2166-2172. 
Sies H. 1991: Oxidative stress: from basic research to clinical application. American Journal of Medicine 91 (3C): 31-38. DOI: 10.1016/0002-9343(91)90281-2

Stratil P., Klejdus B. \& Kuban V. 2007: Determination of phenolic compounds and their antioxidant activity in fruits and cereals. Talanta 71: 1741-1751. DOI: 10.1016/j.talanta.2006.08.012

Tausz M., Šircelej H. \& Grill D. 2004: The glutathione system as a stress marker in plant ecophysiology: is a stressresponse concept valid? Journal of Experimental Botany 55 (404): 1955-1962. DOI: 10.1093/jxb/erh194

Visiné Rajczi E., Hofmann T. \& Albert L. 2017: Peroxidáz és polifenol-oxidáz enzim aktivitás és az összfehérje tartalom, mint a bükk (Fagus sylvatica L.) klimatikus adaptációjának lehetséges indikátorai. In: Bidló A. \& Facskó F. (eds): Soproni Egyetem Erdőmérnöki Kar VI. Kari Tudományos Konferencia Absztraktkötet. Soproni Egyetem Kiadó, Sopron, 260-263.

Zolfaghari R., Hosseini S. M. \& Korori S. A. A. 2010: Relationship between peroxidase and catalase with metabolism and environmental factors in Beech (Fagus orientalis Lipsky) in three different elevations. International Journal of Environmental Sciences 1: 243-252.

Érkezett: 2018. április 3.

Közlésre elfogadva: 2018. szeptember 17. 